\title{
SERANGAN HAMA KUTU DAUN PADA BERBAGAI GENOTIPE TANAMAN SORGUM (Sorghum bicolor [L.] Moench) YANG DITANAM SECARA MONOKULTUR DAN TUMPANGSARI DENGAN TANAMAN UBIKAYU
}

\section{APHIDS ATTACK ON VARIOUS GENOTYPES OF SORGHUM (Sorghum bicolor [L.] Moench) PLANTED IN MONOCULTURE AND INTERCROPPING WITH CASSAVA PLANTS}

\author{
M. Eldhino Mardhitiar Alayubie ${ }^{1 *}$, F. X. Susilo², M. Syamsoel Hadi ${ }^{3}$, dan Lestari Wibowo ${ }^{2}$ \\ ${ }^{1}$ Jurusan Agroteknologi, Fakultas Pertanian, Universitas Lampung, Bandar Lampung, Indonesia \\ ${ }^{2}$ Jurusan Proteksi Tanaman, Fakultas Pertanian, Universitas Lampung, Bandar Lampung, Indonesia \\ ${ }^{3}$ Jurusan Agronomi dan Hortikultura, Fakultas Pertanian, Universitas Lampung, Bandar Lampung, Indonesia \\ *Email: muhammadeldhino8@gmail.com
}

*Corresponding Author, Diterima: 23 Maret 2021, Direvisi: 10 Mei 2021, Disetujui: 8 Ags. 2021

\section{ABSTRACT}

This experiment aimed to determine the effect of sorghum genotype and sorghum cropping pattern (intercropping versus monoculture) on the level of aphids attack on sorghum plants. In the experimental plots, 1) intercropping of sorghum-cassava, 2) the use of 15 genotypes of sorghum, and 3) observed the attack of aphids on sorghum plants. The research was conducted at the Integrated Field Laboratory of the Faculty of Agriculture, University of Lampung from March to August 2017. The treatments were arranged in a split plot design with the main plot being cropping patterns (intercropping and monoculture) and the subplots were 15 genotypes of sorghum, with three replications (block). Variance of the data were analyzed (significant level 0.01 or 0.05), followed by the smallest significant difference test (BNT) at a significance level of 0.05. The results showed that the sorghum genotype had a significant effect on the attack of aphids. The GH-13 genotypes were susceptible to aphid attacks. The GH-3, GH-7, Super 2, P/ F 5-193C, and Talaga Bodas genotypes were moderately resistant to aphids. The genotype that resistant to aphids was P/I WHP. Genotypes GH-4, GH-5, GH-6, Samurai 1, Super 1, Numbu, Mandau, and UPCA were moderately resistant to aphids. In addition, it was seen that intercropping and monoculture had a significant effect on aphids attack, intercropping can reduce aphids attack on sorghum plants.

Keywords: Aphids, cropping pattern, genotype, sorghum.

\begin{abstract}
ABSTRAK
Percobaan ini bertujuan untuk mengetahui pengaruh genotipe tanaman sorgum dan pola tanam sorgum (tumpangsari versus monokutur) terhadap tingkat serangan hama kutu daun pada tanaman sorgum. Pada plot-plot percobaan dilakukan 1) penanaman tumpangsari tanaman sorgum-ubikayu, 2) penggunaan 15 genotipe sorgum, dan 3) pengamatan terhadap serangan hama kutu daun pada tanaman sorgum. Penelitian dilakukan di Laboratorium Lapangan Terpadu Fakultas Pertanian Universitas Lampung dari Maret sampai Agustus 2017. Perlakuan disusun dalam Rancangan Petak Terbagi (split plot design) dengan petak utama adalah pola tanam (tumpangsari dan monokultur) dan anak petak adalah 15 genotipe sorgum, dengan tiga ulangan (blok). Data dianalisis ragam (taraf
\end{abstract}


nyata 0,01 atau 0,05 ), dilanjutkan uji beda nyata terkecil(BNT) pada taraf nyata 0,05 . Hasil penelitian menunjukkan bahwa genotipe sorgum berpengaruh nyata terhadap serangan hama kutu daun. Genotipe GH-13 rentan terhadap serangan kutu daun.Genotipe GH-3, GH-7, Super 2, P/F 5-193C, dan Talaga Bodas ketahanannya sedang cenderung rentan terhadap serangan kutu daun. Genotipe yang tahan terhadap serangan kutu daun yaitu P/I WHP. Genotipe GH-4, GH-5, GH-6, Samurai 1, Super 1, Numbu, Mandau, dan UPCA ketahanannya sedang cenderung tahan terhadap kutu daun. Selain itu terlihat bahwa pola tanam tumpangsari dan monokultur berpengaruh nyata terhadap serangan kutu daun yakni pola tanam tumpangsari dapat menurunkan serangan kutu daun pada tanaman sorgum.

Kata kunci : Genotipe, kutu daun, pola tanam, sorgum.

\section{PENDAHULUAN}

Sorgum (Sorghum bicolor [L.] Moench) merupakan tanaman pangan serealia yang mempunyai daya adaptasi yang tinggi. Sorgum lebih tahan terhadap kekeringan bila dibandingkan dengan tanaman serealia lainnya serta dapat tumbuh hampir di setiap jenis tanah. Sorgum tahan terhadap kondisi yang panas dan kering karena adanya lapisan lilin pada batang dan daun sorgum yang dapat membantu mengurangi kehilangan air melalui penguapan (transpirasi tanaman). Hal tersebut yang memungkinkan sorgum memiliki potensi untuk dikembangkan menjadi salah satu tanaman alternatif untuk memenuhi kebutuhan bahan pangan, pakan serta industri(House, 1995). Namun potensi tersebut belum dapat dimanfaatkan sepenuhnya karenaberbagai kendala yang meliputi faktor sosial, ekonomi, dan budaya, serta pembudidayaannya seperti adanya serangan hama.

Menurut Shannag et al.(2007), kutu daun merupakan hama yang banyak menyerang tanaman sorgum, terutama saat musim kemarau. Kutu daun menyerang tanaman dengan cara menghisap cairan tanaman dan menghasilkan ekskresi berupa substansi gula yang disebut embun madu, sehingga selain mengakibatkan kerusakan langsung pada tanaman karena hisapan, hasil ekskresinya juga dapat mendukung pertumbuhan cendawan jelaga. Pencegahan kehilangan hasil akibat serangan kutu daun dapat dilakukan dengan beberapa cara pengendalian diantaranya pengaturan pola tanam dan penggunaan genotipe tanaman sorgum.

Kehadiran dan tingkat serangan hama dipengaruhi oleh pola tanam, baik monokultur maupun tumpangsari.Pola tanam monokultur dan tumpangsari memiliki dampak yang berbeda terhadap serangan hama.Penanaman sorgum secara monokultur yang dilakukan beruntun dari musim ke musim, akan memperbesar kelimpahan hama, sedangkan pada pertanaman tumpangsari serangan hama lebih rendah karena adanya diversifikasi tanaman.Sorgum dan ubikayu merupakan dua jenis tanaman yang sesuai untuk ditumpangsarikan. Kedua tanaman ini berasal dari famili yang berbeda, mampu beradaptasi pada lingkungan secara luas dan relatif mempunyai syarat tumbuh yang sama. Selain itu sorgum dan singkong memiliki sistem perakaran yang berbeda sehingga dapat mengurangi kompetisi terhadap unsur hara dalam tanah (Buhairah, 2007). 
Selain pengaturan pola tanam, peningkatan produksi dapat dilakukan dengan penggunaan genotipe tanaman yang tepat.Setiap jenis tanaman memiliki genotipe yang berbeda-beda.Perbedaan tersebut yang menyebabkan tanaman mempunyai respon beragam terhadap lingkungan tumbuhnya. Genotipe yang berbeda akan menunjukkan penampilan yang berbeda setelah berinteraksi dengan lingkungan tertentu. Daya adaptasi yang berbeda tersebut dapat mempengaruhi intensitas serangan kutu daun pada tanaman sorgum (Gomez dan Gomez, 1995 ; dalam Hartati et al., 2013).

Berdasarkan banyaknya potensi yang dimiliki tanaman sorgum maka perlu diupayakan peningkatan produksi sorgum melalui pengaturan pola tanam dan penggunaan genotipe sorgum. Dengan demikian penelitian ini bertujuan untuk mengetahui pengaruh pola tanam dan genotipe sorgum terhadap tingkat serangan hama kutu daun.

\section{BAHAN DAN METODE}

Tempat dan waktu.Penelitian ini dilaksanakan pada di Laboratorium Lapangan Terpadu Fakultas Pertanian Universitas Lampung. Lahan percobaan berlokasi di Jl. Sumantri Brojonegoro No. 1, Gedong Meneng, Kecamatan Rajabasa, Kota Bandar Lampung. Secara geografis lokasi penelitian ini terletak antara 5'22'11.38" LS dan 105¹4'25.96" BT sampai 5021'58.35" LS dan $105^{0} 14^{\prime} 43.83$ " BT. Penelitian berlangsung dari bulan Maret sampai dengan bulan Agustus 2017.

Bahan dan Alat. Bahan yang digunakan untuk penelitian ini antara lain 15genotipe sorgum dan stek ubikayu. Genotipe - genotipe sorgum yang digunakan yaitu Numbu, UPCA, Mandau, Talaga Bodas, P/F 5 - 193C, P/I WHP, GH-3, GH-4, GH-5, GH-6, GH7, GH-13, Samurai 1, Super 1, dan Super 2. Stek tanaman ubikayu yang digunakan ialah varietas Kasetsart (UJ-5). Alat yangdigunakan antara lain cangkul, papan nama genotipe, tali plastik, gembor, selang air, kamera,gunting, mistar,alat tulis,spidol permanen, dan bukukunci determinasi serangga.

Pelaksanaan Penelitian. Percobaan disusun menggunakan Rancangan Petak Terbagi (Split Plot Design) yang terdiri dari petak utama dan anak petak. Petak utama adalah pola tanam (monokultur dantumpangsari),sedangkan anak petak adalah 15 genotipe sorgum (UPCA, P/F 5 - 193C, P/I WHP, Mandau, Numbu, Talaga Bodas, GH-3, GH-4, GH5, GH-6, GH-7, GH-13, Samurai 1, Super 1, dan Super 2). Percobaan dilakukan dengan 3 kali ulangan. Total satuan percobaan adalah $(2 \times 15) \times 3=90$ satuan percobaan.

Pengolahan tanah dilakukan dengan menggemburkan tanah yang ditanami dan membersihkan tanah dari sisa - sisa akar tanaman. Pertanaman monokultur sorgum dan tumpang sari sorgum-ubi kayu disiapkan pada lahan percobaan seluas $12 \mathrm{~m} \times 20 \mathrm{~m}$. Lahan percobaan dibagi enam petak percobaan yang masing-masing berukuran $12 \mathrm{~m} \times 2,5 \mathrm{~m}$, dengan jarak antar petak 0,5 m. Kemudian dibuat guludan menggunakan cangkul. Sorgum ditanam dengan jarak tanam $20 \mathrm{~cm} \times 80 \mathrm{~cm}$ dengan 3-5 benih sorgum per lubang dan ubikayu ditanam dengan jarak tanam $80 \mathrm{~cm}$ x $60 \mathrm{~cm}$. Di dalam petak monokultur terdapat 15 baris tanaman sorgum yang terdiri dari 15 genotipe sorgum sedangkan pada petak tumpangsari 
sorgum ditanam diantara barisan ubikayu. Dalam hal ini satu baris genotipe sorgum dianggap sebagai 1 satuan percobaan. Kedua komoditas ditanam secara bersamaan dan diberi papan nama genotipe.

Pengamatan.Variabel yang diamati pada penelitian ini adalah tingkat serangan serangga hamakutu daun pada tanaman sorgum.Pengamatan kutu daun dilakukan pada pagi hari,setelah tanaman berumur 3 minggu selama 8 minggu dengan selang waktu seminggu sekali. Pengamatan dilakukan terhadap setiap tanaman yang ada di dalam baris tanaman sorgum. Tingkat serangan hama kutu daun dihitung dengan rumus sebagai berikut.

$$
P=\frac{a}{b} \times 100 \%
$$

dengan catatan $\mathrm{a}=$ jumlah tanaman di dalam baris tanaman sorgum yang terserang serangga hama (kutu daun) dan $b=$ jumlah seluruh tanaman didalam baris tanaman sorgum.

Analisis Data. Untuk menguji homogenitas ragam digunakan uji Bartlett dan aditivitas data diuji dengan menggunakan uji Tukey. Kedua uji tersebut dilakukan pada taraf nyata 0,05 . Setelah asumsi terpenuhi, dilakukan analisis ragam (ANARA) pada taraf nyata 0,01 atau 0,05 dan uji perbedaan nilai tengah perlakuan dengan uji beda nyata terkecil (BNT)pada taraf nyata 0,05 .

\section{HASIL DAN PEMBAHASAN}

Tingkat Serangan Hama Kutu Daun pada 15

\section{Genotipe Tanaman Sorgum}

Secara umum dari kelimabelas genotipe tanaman sorgum yang rentan terhadap serangan hama kutu daun yaitu genotipe sorgum GH-13 (Gambar 1). Tingkat serangan kutu daun terhadap genotipe sorgum GH-13 mulai terjadi peningkatan dari pengamatan minggu pertama (3 MST) hingga pengamatan minggu ke lima (7 MST).Akan tetapi tingkat serangan kutu daun berangsur-angsur menurun seiring bertambahnya umur tanaman, terlihat pada8 MST, 9 MST, dan 10 MST.

Hasil penelitian keseluruhan genotipe tanaman sorgum dari pengamatan minggu pertama hingga minggu ke delapan terlihat tingkat serangan kutu daun pada minggu pertama (3 MST) dan minggu ke dua (4 MST) tergolong rendah namun mengalami kenaikan

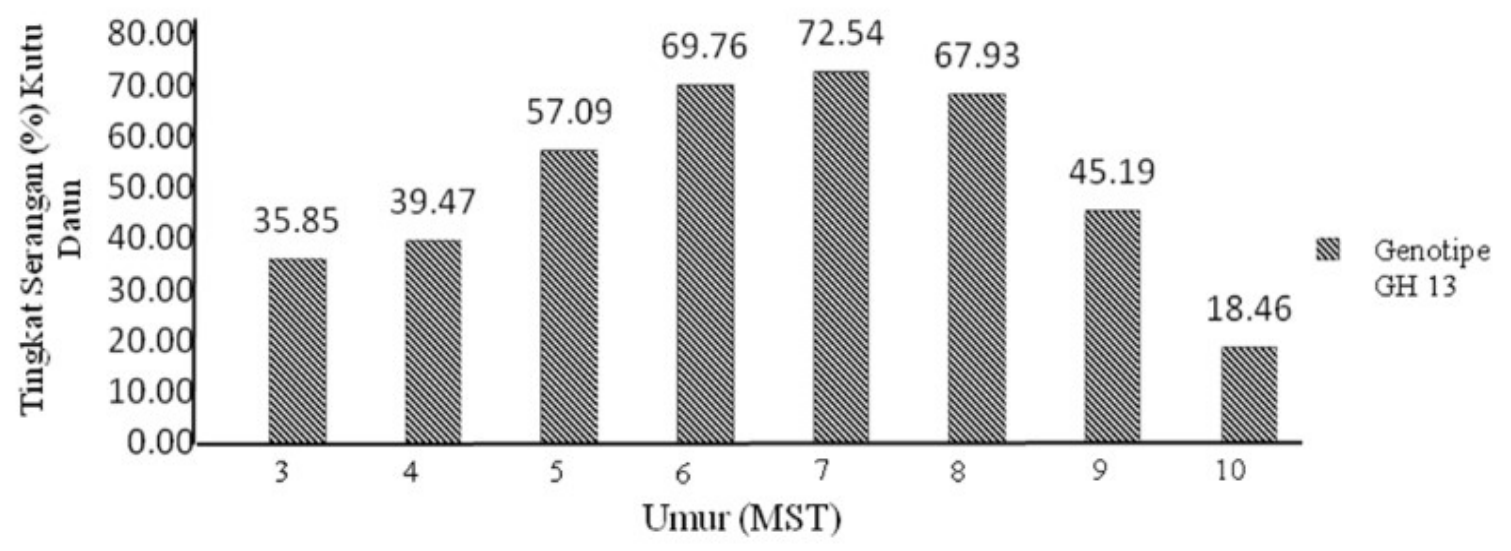

Gambar 1. Tingkat serangan hama kutu daun pada genotipe sorgum GH-13. Keterangan: MST= Minggu setelah tanam. 
yang signifikan pada pengamatan minggu ke enam (8 MST) lalu mengalami penurunan kembali pada pengamatan minggu ke tujuh(9MST).Tingkat serangan kutu daun terendah yakni pada pengamatan minggu kedelapan (10 MST) (Gambar 2).

Tingkat Serangan Hama Kutu Daun pada Pola Tanam Tumpangsari vs Monokultur

Hasil pengamatan pada minggu pertama (3MST) hingga pengamatan minggu kedelapan (10 MST) menunjukkan tingkat serangan hama kutu daun pada pola tanam monokultur lebih tinggi dibandingkan dengan pola tanam tumpangsari. Tingkat serangan kutu daun tertinggi baik pada polam tanam tumpangsari maupun pada pola tanam monokultur terlihat (Tabel 1) pada pengamatan minggu keenam (8 MST) dan mengalami penurunan pada pengamatan minggu ketujuh (9 MST), tingkat serangan terendah terlihat pada pengamatan minggu kedelapan (10 MST).

Tingkat Serangan Kutu Daun pada 15 Genotipe Tanaman Sorgum yang Ditumpangsari vs Monokultur

Hasil penelitian menunjukkan (Gambar 3) bahwa 15 genotipe sorgum yang ditanam secara tumpangsari vs monokultur berpengaruh nyata terhadap
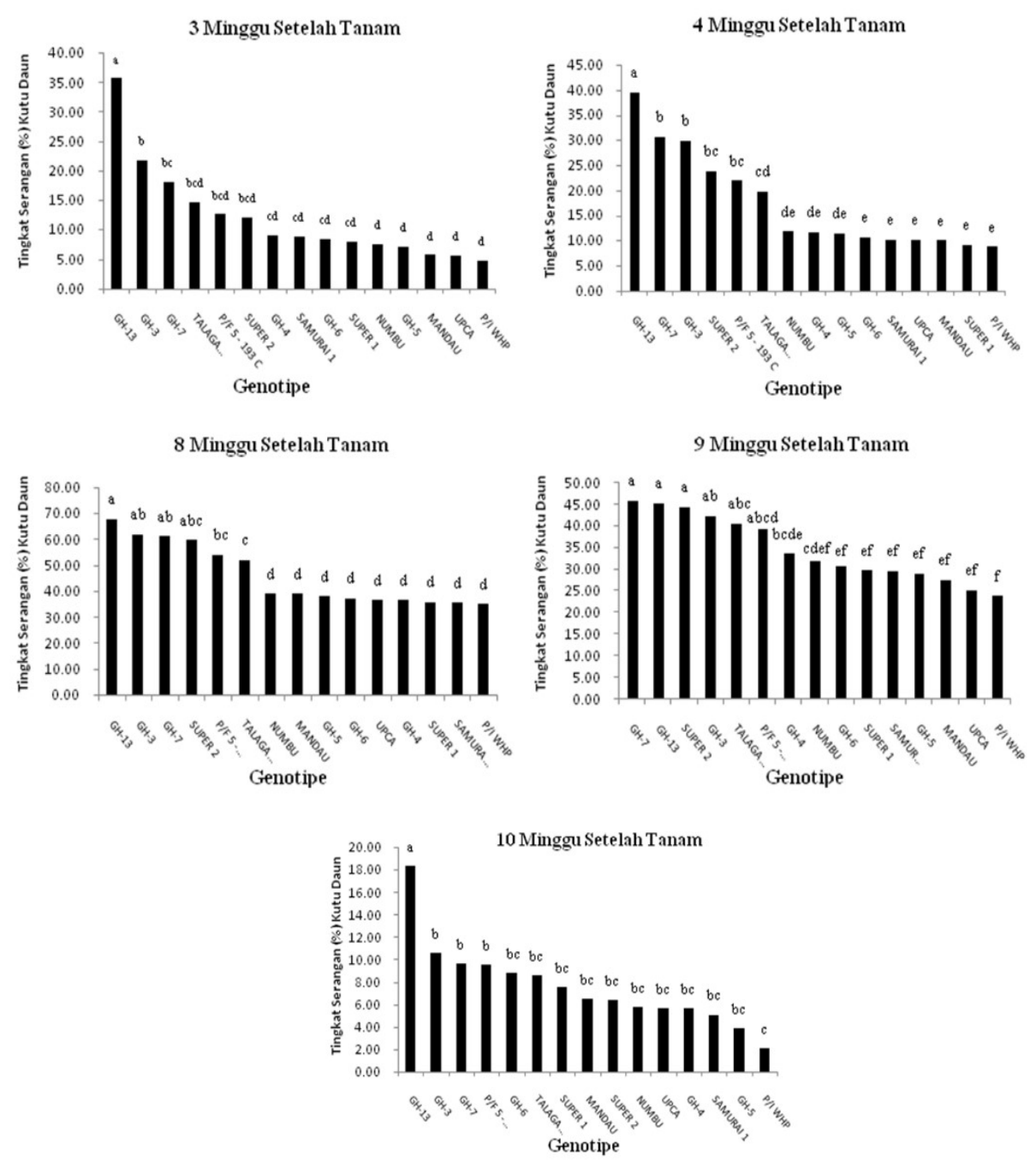

Gambar 2.Tingkat serangan kutu daun pada tanaman sorgum (3 MST, 4 MST, 8 MST, 9 MST dan 10 MST). (Keterangan : MST = Minggu setelah tanam). 
tingkat serangan kutu daun pada 5 MST, 6 MST, dan

7 MST. Genotipe sorgum yang memperlihatkan sifat rentan terhadap serangan kutu daun yaitu $\mathrm{GH}-13$ secara konsisten rentan, baik pada pola tanam monokultur dan tumpangsari kemudian genotipe P/I WHP menunjukkan sifat tahan secara genotipe terhadap kutu daun pada pola tanam monokultur maupun tumpangsari. Selain itu Gambar 3 menunjukkan bahwa genotipe sorgum yang ketahanannya sedang cenderung rentan memiliki baikpada pola tanam monokultur dan tumpangsari. Sedangkan genotipe sorgum yang ketahanannya sedang cenderung tahan juga memiliki sifat yang sama dengan genotipe yang tahanapabila ditanam secara monokultur, namun ketahanannya meningkat jika ditumpangsarikan. Hal tersebut dapat diilustrasikan pada gambar 4. sifat yang sama dengan genotipe sorgum yang rentan,

\section{Pembahasan}

Dalam penelitian ini kutu daun menyerang tanaman sorgum sejak pengamatan pertama (3 MST)secara berkoloni. Namun tingkat serangannya masih tergolong rendah $(<10 \%)$, kecuali pada genotipe GH-13, GH-3, GH-7, Talaga Bodas, P/F 5-193 C, dan Super 2. Pada pengamatan minggu ke dua (4 MST) tingkat serangan kutu daun mengalami kenaikan yakni hampir semua genotipe tanaman sorgum tingkat serangannya $(<10 \%)$, kecuali pada genotipe P/I WHP dan Super 1. Hal ini sesuai dengan penelitian Teeteset al. (1983), yang menyatakan bahwa kutu daunmenyerang tanaman sorgum mulai dari fase pembibitan yaitu pada saat pelepah daun ke-3 terlihat (10-14 HST).Dari hasil pengamatan terlihat bahwa tingkat serangan kutu daun meningkat cukup cepat
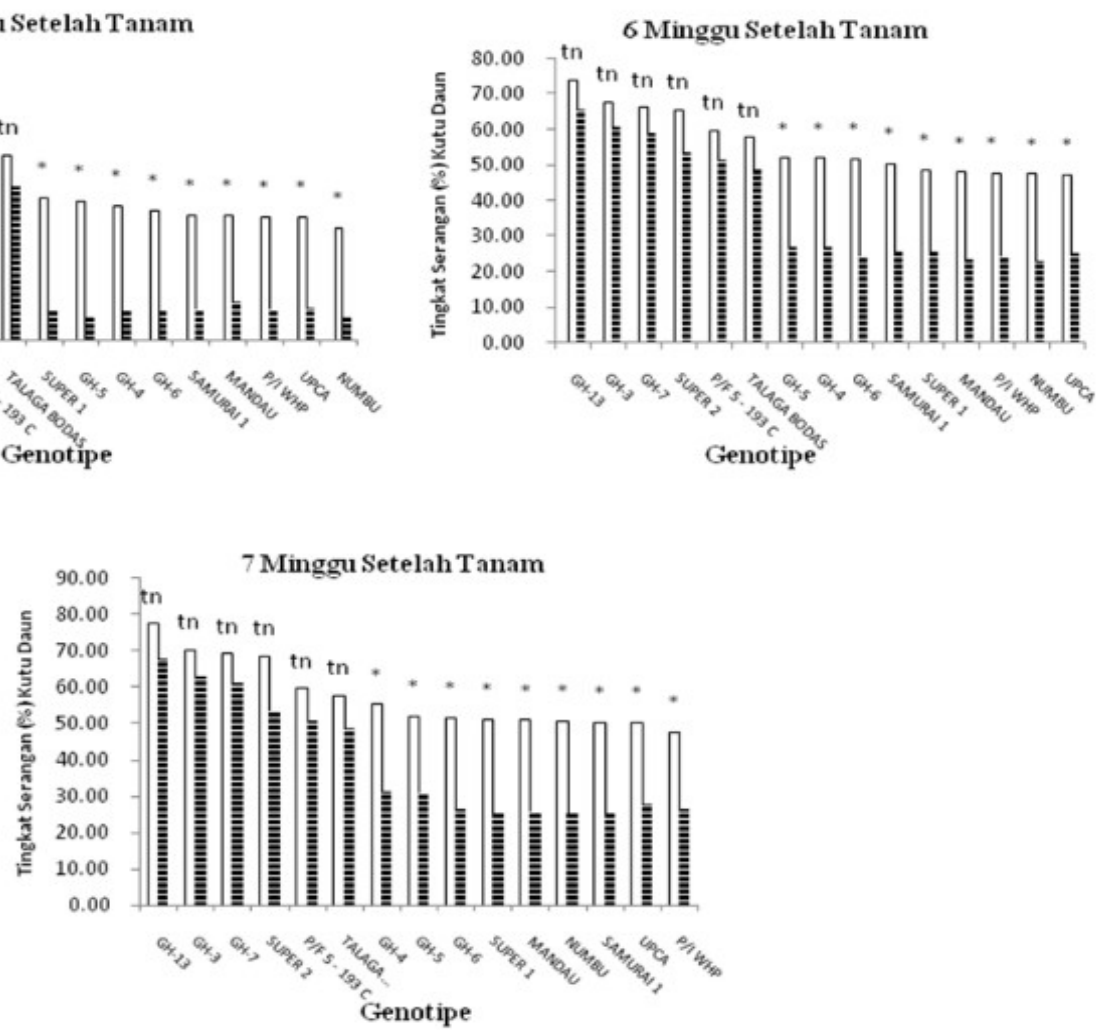

Gambar 3. Tingkat serangan kutu daun pada tanaman sorgum (5 MST, 6 MST, dan 7 MST). (Keterangan : MST = Minggu setelah tanam; $\square=$ Monokultur; $\mathbf{~ = ~ T u m p a n g s a r i ) . ~}$ 
Tabel 1. Tingkat serangan kutu daun pada dua pola tanam (tumpangsari vs monokultur).

\begin{tabular}{|c|c|c|c|c|c|c|c|c|c|}
\hline \multirow{2}{*}{ Pola Tanam } & \multicolumn{9}{|c|}{ Tingkat Serangan (\%) } \\
\hline & $3 \mathrm{MST}$ & & $4 \mathrm{MS}$ & & $8 \mathrm{MST}$ & & $9 \mathrm{MST}$ & & $10 \mathrm{MST}$ \\
\hline Monokultur & 17,48 & $\mathrm{a}$ & 21,32 & $\mathrm{a}$ & 55,21 & $\mathrm{a}$ & 44,46 & $\mathrm{a}$ & 9,25 \\
\hline Tumpangsari & 6,74 & $\mathrm{~b}$ & 13,25 & $\mathrm{~b}$ & 36,73 & $\mathrm{~b}$ & 24,74 & $\mathrm{~b}$ & $6,15 \quad 1$ \\
\hline $\mathrm{BNT}_{0,05}$ & 3,75 & & 3,17 & & 3,04 & & 3,23 & & 2,66 \\
\hline
\end{tabular}

Keterangan: Nilai pada lajur yang diikuti huruf yang sama tidak berbeda nyata menurut uji BNT 0,05.

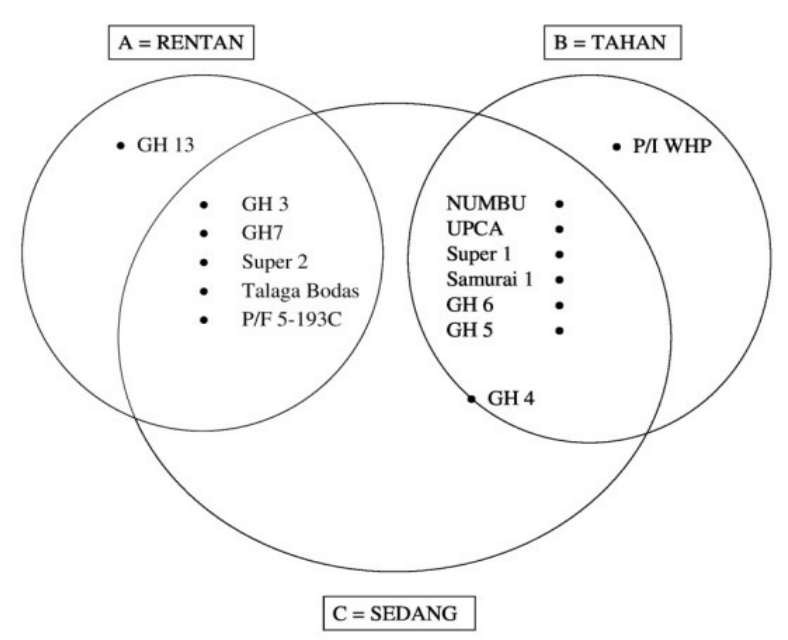

Gambar 4. Penggolongan tingkat ketahanan / kerentanan 15 genotipe sorgum terhadap serangan kutu daun.

setiap minggunya, walaupun ada variasi antar genotipenya. Menurut Ratcliffe et al.(2004), kutu daun menyukai tanaman sorgum sebagai tanaman inangnya, namun ia juga menyerang tanaman jagung, padi, dan beberapa tanaman lainnya dari famili Gramineae.

Tingkat serangan tertinggi terjadi pada pengamatan minggu ke enam (8 MST) yakni antara 34 - 67\%.Pada umur tanaman 8 MST, tanaman sorgum telah masuk fase generatif yaitu segera setelah muncul daun bendera. Menurut Sharma and Nwanze (1997), populasi kutu daun meningkat pada fase generatif. Hal tersebut diakibatkan pada fase generatif sorgum memiliki lebih banyak variasi bagian tanaman dibandingkan dengan fase bibit dan fase vegetatif. Pada fase generatif tanaman sorgum, populasi kutudaun tersebar pada bagian daun, batang, pelepah, dan malai sorgum.
Genotipe GH-13 merupakan genotipe yang rentan terhadap kutu daun, hal tersebut terlihat pada pengamatan minggu pertama (3 MST) hingga minggu keenam (8 MST) dan minggu kedelapan(10 MST) yang menunjukkan bahwa GH-13 memiliki tingkat serangan kutu daun tertinggi. Selain GH-13 terlihat bahwagenotipe sorgum GH-3, GH-7, Super 2, P/F 5 - 193 C, dan Talaga Bodas yang ketahanannya sedang cenderung rentan terhadap kutu daun karena pada pengamatan minggu ke enam tingkat serangannya mencapai $>50 \%$. Genotipe P/I WHP merupakan genotipe yang tahan terhadap serangan kutu daun.Genotipe UPCA, Mandau, GH-5, Numbu, Super 1, GH-6, Samurai 1, GH-4 merupakan genotipe sorgum yang ketahanannya sedang cenderung tahan. Hal tersebut terlihat pada pengamatan ke enam tingkat serangannya berkisar $<50 \%$. 
Hasil penelitian ini menunjukkan bahwa15 genotipe tanaman sorgum memiliki tingkat serangan kutu daun yang berbeda.Adanya perbedaan tingkat serangan pada 15 genotipe tanaman sorgum dipengaruhi oleh faktor genetik.Hasil pengujian Sharma (1985), pada beberapa jenis varietas sorgum dengan berbagai keragaman genetik menunjukkan adanya perbedaan tingkat ketahanan yang dimiliki.Hal ini berpengaruh pula terhadap perkembangan suatu hama, yakni pada varietas tahan akan lebih lambat dibandingkan dengan varietas yang rentan. Secara genetik sifat ketahanan tanaman dipengaruhi oleh adanya sejumlah gen yang menyusun kromosom, pada varietas tahan biasanya disusun oleh beberapa gen tahan yang dikenal dengan ketahanan horizontal. Selanjutnya dapat pula dipengaruhi oleh adanya produksi metabolisme berupa fitoaleksin yang dihasilkan oleh tanaman yang bisa menetralisir infeksi yang disebabkan oleh patogen tanaman, sehingga tanaman dapat mempertahankan diri dari serangan hama.

Pola tanam berpengaruh terhadap tingkat serangan kutu daun pada tanaman sorgum (Tabel 1). Tingkat serangan hama tertinggi baikpada pengamatan minggu pertama (3 MST) hingga minggu ke delapan (10 MST) yaitu pada pola tanam monokultur. Diperkirakan hal ini disebabkan oleh pertanaman monokultur yang menyediakan sumber makanan bagi hamakutu daun terkonsentrasi pada tanaman sorgum saja dan dalam jumlah yang banyak sehingga hama dapat bereproduksi dan bertahan di tanaman sorgum. Sebagaimana dikemukakan olehNurindah(2006), bahwa peningkatan keragaman vegetasi melalui pola tanam tumpangsari, merupakan salah satu prinsip utama dalam pengelolaan agroekosistem untuk pengendalian hama karena keragaman populasi dan predator relatif tinggi.

\section{KESIMPULAN}

Dari penelitian ini dapat disimpulkan bahwa genotipe tanaman sorgum dan pola tanam sorgum mempengaruhi tingkat serangan kutu daun pada tanaman sorgum. Genotipe tanaman sorgum mempengaruhi tingkat serangan kutu daun. Genotipe tanaman sorgum yang rentan terhadap serangan kutu daun yaituGH-13, dan genotipe tanaman sorgum yang tahan terhadap serangan kutu daun yaitu P/I WHP. Sedangkan genotipe GH-3, GH-7, Super 2, Talaga Bodas, dan P/F 5-193C memiliki ketahanan yang sedang cenderung rentan.Kemudian, genotipe GH-4, GH-5, GH-6, UPCA, Mandau, Numbu, Super 1, dan Samurai 1 memiliki ketahanan yang sedang cenderung tahan terhadap serangan kutu daun. Pola tanam mempengaruhi tingkat serangan kutu daun pada pertanaman sorgum. Tingkat serangan kutu daun lebih rendah pada tanaman sorgum yang ditumpangsarikan dengan ubikayu dibandingkan pada tanaman sorgum monokultur.

\section{DAFTAR PUSTAKA}

Buhairah.2007. Respon kacang tanah (Arachis hypogaea L.) dan jagung (Zea mays L.) terhadap beberapa pengaturantanam jagung pada sistem tanam tumpang sari. Jurnal Agronomi 11(1): 41-45.

Hartati, S., M. Barmawi, dan N. Sa'diyah. 2013. Pola segresi karakter agronomi tanaman kedelai (Glycine max [L.] Merrill) generasi $\mathrm{F}_{2}$ hasil 
persilangan Wilis x B3570. J. Agrotek Tropika $1(1): 8-13$.

House, L. R. 1995. A Guide to sorghum breeding. International Crops Research Institute for Semi Arid Tropics. Andhra Pradesh. India. $206 \mathrm{p}$.

Nurindah. 2006. Pengelolaan agroekosistem dalam pengendalian hama. Jurnal Perspektif 5 (2) : 78-85.

Ratcliffe S.T., M.E. Gray, and K. L. Steffey. 2004. Corn Leaf Aphid Rhopalosiphum maidis. Champaign: Integrated Pest Management 1: 1-3.

Shannag, H. K., J. M. Al-Qudah, I. M. Makhadmeh, and N. M. Freihat. 2007. Differences in growth and yield responses to Aphis gossypii Glover between different okra varieties. J. Plant. Protect. Sci43(3): 109-116.
Sharma, H. C., and K. F. Nwanze. 1997. Insect pest of sorghum: biology, extent oflosses, and economic thresholds. Pages 9-23 in Plant resistence to insect in sorghum (Sharma, H. C., Faujdar Singh, and Nwanze.K. F., eds.). Patancheru 502 324. Andhra Pradesh. India. International Crops Research Institute for the Semi-Arid Tropics.

Sharma, H.C. 1985. Screening for Host-Plant Resistence to Mirid Head Bugs in Sorghum. Proceedings of the International Sorghum Entomology Workshop Texas A\&M University.USA. 15-21 July 1984.

Teetes, G. L., K. V. Seshu Reddy, K. Leuscher, and L. R. House. 1983. Sorghum insect identification handbook. Information Bulletin No. 12. Patancheru. India. International Crops Research Institute fot the Semi-Arid Tropics. USA. 128 p. 